\title{
International development volunteering: An instrument for promoting education in line with the Sustainable Development Goals?
}

\author{
Laura Scheinert ${ }^{\star}$ - University of Exeter, UK \\ Kerstin Guffler, Jan Tobias Polak and Martin Bruder - German Institute for \\ Development Evaluation (DEval), Germany
}

\begin{abstract}
Education is one of the central tenets of the United Nations 2030 Agenda for Sustainable Development. International volunteer services (IVS) in development often aim to provide volunteers with knowledge and skills needed in a globalized world. We use the case of the German weltwärts programme, one of the largest IVS worldwide, to investigate how far IVS can be viewed as an instrument promoting education in line with the Sustainable Development Goals (SDGs). First, we discuss how weltwärts aligns conceptually with the principles and contents of the SDGs. Second, we present empirical evidence on how far the envisioned principles and education outcomes are achieved on the implementation level. We conclude with a discussion of the potentials and limitations of weltwärts in promoting education in line with the SDGs.
\end{abstract}

Keywords: development volunteering; international volunteering; global learning; Sustainable Development Goals (SDGs); weltwärts

\section{Introduction}

In 2015, the United Nations General Assembly adopted the 2030 Agenda for Sustainable Development, presenting a vision for a just, fair and sustainable future for all. It removes the sole focus on so-called 'developing countries' common to previous development agendas. In laying out its vision for sustainable development, the 2030 Agenda 'pledge[s] that no one will be left behind' (UN, 2015: n.p.). This principle means that services, resources, provisions, activities and so on should reach both 'all segments of society' and allow 'equitable access' (UN, 2015: n.p.) for people of diverse backgrounds and characteristics. One of the central tenets of the 2030 Agenda is its focus on education and the emphasis it places on young people as 'agents of change' (UN, 2015: n.p.) in the promotion of sustainable development.

When looking for ways to promote the vision and goals of the 2030 Agenda, volunteering is often seen as one valuable instrument (Haddock and Devereux, 2015; UNV, n.d.). International volunteer services (IVS) in development for young adults in particular often aim at, inter alia, promoting sustainability and global justice through providing education opportunities for the participating volunteers. Some envisaged individual learning outcomes include: increased intercultural competences (Fitzmaurice, 2013); more knowledge about global dependencies and global (economic) structures, 
and the development of a global citizen awareness (Moore McBride et al., 2012); and changes in volunteers' self-perception, for example increased levels of self-confidence, self-efficacy or openness (Sherraden et al., 2008).

While the examination of the effects of IVS on volunteers is a growing field, few studies have turned an explicit focus on how the educational frameworks and outcomes of IVS relate to the 2030 Agenda and its Sustainable Development Goals (SDGs) (Devereux et al., 2017). Examining existing education instruments, such as IVS, for their conceptual alignment with the 2030 Agenda, and assessing their effectiveness in promoting the education provisions in the SDGs, is vital, as this can lead to the identification of practices that have the potential to contribute to the achievement of the SDGs. Focusing on the German volunteer programme weltwärts - one of the largest IVS worldwide - we seek to answer the following questions:

1. How far do the principles and contents of weltwärts align with the education provisions in the SDGs on the conceptual level?

2. How far does weltwärts achieve education outcomes in line with the SDGs on the implementation level?

We find that, while the aims of weltwärts and education provisions in the SDGs are in overall alignment on the conceptual level, there is a persistent selectivity of weltwärts participants, and education outcomes are only partly achieved. Weltwärts returnees' activities in development-related civic engagement, development education work and sustainable consumption are, however, overall in line with the promotion of sustainable development. This article seeks to contribute to the conversation beginning between IVS and SDGs, highlighting potentials and limitations of IVS as an instrument promoting the SDGs.

\section{Background}

\section{The 2030 Agenda/Sustainable Development Goals}

The 2030 Agenda emphasizes that people in their everyday lives drive the envisioned changes towards achieving sustainable development, towards this transforming of our world: 'individuals must contribute to changing unsustainable consumption and production patterns' and 'children and young women and men are critical agents of change' (UN, 2015: n.p.). Education is seen to be at the heart of empowering these change agents. Not only does it feature in the Agenda's introductory declaration, it is also a goal in itself: SDG 4 is to 'ensure inclusive and equitable quality education and promote lifelong learning opportunities for all' (UN, 2015: n.p.).

Two sub-goals in particular, SDG 4.5 and SDG 4.7, relate to the wider context of promoting sustainable development and an end to inequalities. SDG 4.7 focuses on the 'knowledge and skills needed to promote sustainable development' (UN, 2015: n.p.). While it does not specify what it means exactly by knowledge and skills, it does offer a plethora of ways to achieve them - namely through 'education for sustainable development, sustainable lifestyles, human rights, gender equality, promotion of a culture of peace and nonviolence, global citizenship and appreciation of cultural diversity and of culture's contribution to sustainable development' (UN, 2015: n.p.). The Global Indicator Framework for the operationalization of the SDGs (UN, 2018) puts a focus on mainstreaming global citizenship education and education for sustainable development in education policies and implementation, but does not provide a concrete operationalization of the knowledge and skills stipulated in SDG 4.7 itself. 
SDG 4.5 highlights the importance of 'eliminat[ing] gender disparities [providing] equal access to all levels of education and vocational training for the vulnerable' (UN, 2015: n.p.), including for persons with disabilities, underscoring the principle of 'leave no one behind' alluded to in the introduction. Especially in regard to education, 'all' denotes all persons irrespective of their sex or gender, race or ethnicity, age, disabilities, refugee or migrant status, or indigenous status (UN, 2015: n.p.). The indicators further detail that 'parity indices' should be used to capture any progress made on universal and equitable access to education (UN, 2018). These indices should disaggregate outcomes by sex or gender, location (urban/rural), class or wealth, disabilities, affect of conflict, or indigenous status (UN, 2018). Thus, the Agenda presents a broad range of socio-demographic and socioeconomic characteristics by which to assess whether education instruments, such as IVS, provide universal and equitable access to all.

When looking for instruments to promote the SDGs, volunteering in general has received some attention (Haddock and Devereux, 2015; UNV, n.d.). Findings from the field of international volunteer service research suggest education outcomes in the areas of increased intercultural competence and greater openness to intercultural encounters (Lough et al., 2014; Moore McBride et al., 2012; Yashima, 2010), as well as better language skills, increased host-country knowledge, and increased self-efficacy and self-confidence (Fitzmaurice, 2013; Sherraden et al., 2008). Some IVS, such as the British International Citizen Service, find that volunteers represent a group of people active in civic engagement to above-average levels (Ecorys, 2013). Others show that returnees might shift their engagement focus to development issues and to facilitating education events (Clark and Lewis, 2017; Grobbauer et al., 2008). While these results all point to the potentials of IVS in achieving education outcomes in line with the SDGs, the contribution of individual programmes to promoting the SDGs and the overall vision of the 2030 Agenda remain unclear and rather unexplored (Devereux et al., 2017). We therefore focus on one IVS programme to tease out its conceptual (that is, theoretical), as well as actual (that is, empirical), alignment with the vision and goals of the 2030 Agenda, particularly in regard of education.

\section{The weltwärts programme}

The programme examined is the German IVS weltwärts (www.weltwaerts.de/en/). It makes for an excellent case study: sending approximately 3,400 volunteers per year on assignment, weltwärts is one of the largest youth volunteer services worldwide that pursues an explicit focus on development issues. The programme was initiated by the German Federal Ministry for Economic Cooperation and Development (Bundesministerium für wirtschaftliche Zusammenarbeit und Entwicklung, BMZ) in 2007, less than ten years before the adoption of the SDGs (without explicit reference to them or their drafting process). Since the start, civil society sending organizations in Germany have been consulted in designing the programme, and they have been facilitating programme implementation together with their partners in the host countries. The organizations also provide an education and mentoring programme for the volunteers. Since 2008, volunteers have been sent from Germany to countries listed by the Organisation for Economic Co-operation and Development (OECD)'s Development Assistance Committee (DAC) as developing countries through the socalled North-South component of weltwärts. This is open to young adults between the ages of, generally, 18 and 28, and offers an average length of stay abroad of about one year. A South-North component, under which volunteers from OECD DAC countries 
can undertake a volunteer service in Germany, has been operating since 2013. Other components focus on returnee engagement and activities in development education work (Post-Assignment and Accompanying Measures components). Weltwärts is jointly funded by BMZ and the civil society organizations, and it is steered by both state and civil society actors, and returnee representatives. The remainder of this article will focus on the North-South and Post-Assignment components that have the overall aim of instigating individual learning and motivation for development-related civic engagement in the volunteers upon their return to Germany.

\section{Methods}

The analysis will draw on a recent theory-based impact evaluation of the German IVS weltwärts conducted between 2015 and 2017 (Polak et al., 2017a). The multidisciplinary core evaluation team consisted of four evaluators. All had previous experience with stays abroad and/or intercultural contact programmes of some sort, which was helpful to inform their general understanding of researching a volunteer exchange programme. One team member was a weltwärts volunteer. While their experience usefully contributed to develop an overall greater sensitivity about weltwärts specifics, analyses and results were always discussed and consolidated with the whole team, to minimize potential bias due to personal preferences or views. Their volunteering experience dates back to six years before joining the evaluation team, and none of the team members had been, or are currently, employed with any of the organizations pertaining to the state or civil society actors involved in implementing weltwärts. Furthermore, the evaluation was conducted on an independent basis, that is, it did not depend on terms of reference or explicit funding from any of the stakeholder organizations.

We implemented a mixed methods approach that combined document analysis to construct a programme theory as the underlying basis for operationalizing outcomes and impact hypotheses, survey-based techniques to quantitatively assess the effectiveness of the programme (whether the theoretically assumed outcomes were achieved in practice), and qualitative focus group discussions to complement the quantitative outcome analysis. This approach put our empirical analysis on a sound theoretical basis and allowed us to first establish what the weltwärts programme wants to achieve (programme theory) and, second, to empirically test if the programme achieved its assumed aims (quantitative and qualitative empirical data). This two-step approach also helps to answer the research questions of this article.

For the question of conceptual alignment (the first research question), we use the programme theory of weltwärts to tease out the principles and contents put forward in the weltwärts programme. A programme theory is 'an explicit theory ... of how an intervention contributes to a set of specific outcomes through a series of intermediate results' (Funnell and Rogers, 2011: 31). In contrast to most scientific studies in social sciences, evaluations analyse the effects of specific interventions. Scientific theories thus need to be incorporated into the assumptions about outcomes of the intervention and mechanisms explaining these outcomes. The programme theory uses these theories and incorporates them into a conceptual framework for an intervention. First, to construct a programme theory of weltwärts, the evaluation team reviewed and coded all available programme and strategy documents - specifically the BMZ's Funding Guideline for the weltwärts programme (BMZ, 2016), the strategy documents 
on the Post-Assignment and Accompanying Measures components (BMZ, 2014; Engagement Global, 2012), the intervention logic from an earlier weltwärts evaluation (Stern et al., 2011) and three other confidential internal documents. At the same time, they conducted conversations with the persons involved in programme steering to identify the inputs, activities, outputs, outcomes and impacts assumed by the weltwärts programme (so-called faithful reconstruction; see EuropeAid Co-operation Office Joint Evaluation Unit, 2006). In a second step (logical reconstruction; see EuropeAid Co-operation Office Joint Evaluation Unit, 2006), this was complemented with the latest scientific findings on IVS and other similar forms of stays abroad, for example exchange and study programmes (drawing on Lemmer and Wagner, 2015; Pettigrew and Tropp, 2006; Walther, 2013; Zimmermann and Neyer, 2013). Finally, the programme theory was discussed and approved with the evaluation's stakeholders (a reference group formed of decision-makers from BMZ and Engagement Global, civil society sending organizations, and volunteer representatives), so that it represents a consolidated basis for the evaluation. To answer the first research question, we will, on the conceptual level, relate the expected learning outcomes detailed in the weltwärts programme theory to the principles and education provisions of the 2030 Agenda.

Having thus established the theoretical underpinnings of the weltwärts programme, its programme theory then served as the basis for operationalizing the envisioned outcomes and hypotheses about individual learning and change (addressing the second research question, on outcome achievement). The outcome variables were measured using a standardized online questionnaire, which was administered to all returned weltwärts cohorts (2009-15 cohorts; questionnaire open between 5 August and 4 October 2016) and the cohort departing at the time of data collection (2016 cohort; questionnaire open between 12 July and 20 October 2016). (An overview of the operationalization and item texts underlying the outcomes analysed in this article is reported in the Appendix, Table A.) Invitations to take part in the survey were sent out by email. Participation was voluntary, informed consent was collected at the start of the survey, and information about data protection and data usage was provided. A total of 28,015 (then) current and returned weltwärts volunteers constituted the survey sample. For analysis, only those respondents who had completed at least 50 per cent of the questionnaire were included, which resulted in an analysis sample of 7,940 people.

For the assessment of whether or not the weltwärts programme achieved its education outcomes, we implemented a quasi-experimental design that compares the cross-sectional survey data from the volunteers surveyed both pre-departure (2016 cohort) and post-assignment (2015 cohort), and from a comparison group of individuals who did not participate in weltwärts but fulfilled the socio-demographic criteria for inclusion in the weltwärts target group. Participants for the comparison group survey (open between 26 August and 26 September 2016) were recruited using eight online-access panels and administered a questionnaire after the completion of a short screening survey to ensure that they fulfilled the comparison group inclusion criteria. Of the respondents, 5,022 completed the questionnaire to at least 50 per cent, and were thus included in the analysis. Propensity score matching (PSM; Rosenbaum and Rubin, 1983) - a statistical procedure that makes persons in the treatment group and persons in the comparison group comparable - enabled the construction of the treatment group (that is, volunteers: matched sample of departing volunteers: 466 persons; matched sample of returning volunteers: 489 persons) and comparison group (that is, non-volunteers: matched sample of the departing volunteers' 
comparison group: 466 persons; matched sample of the returning volunteers' comparison group: 489 persons).

For items with a general focus, for example on general attitudes, the analyses calculated the difference in scores of returning and departing volunteers and the difference in scores within the comparison groups, as well as the difference between these two (so-called difference-in-differences analysis, DiD; see Angrist and Pischke, 2009; Cerulli, 2015). For items with a specific focus, for example on attitudes relating to the volunteers' host country, simple mean-value difference tests (t-tests) were performed using data from only the departing and returning volunteers. (For a more detailed discussion of methodological issues, see Polak et al., 2017a; Guffler et al., 2018.)

The quantitative survey data were complemented by qualitative data from focus group discussions with returned volunteers (total of eight focus groups with 2 to 14 participants, with a total of 68 participants). Participants were recruited: (1) as ad hoc groups, through expressions of interest at the end of the online questionnaire and then selected based on their cohort membership, country of service, overall satisfaction with participation in weltwärts, and socio-demographic variables to obtain cohort-homogeneous but experience-heterogeneous groups; and (2) as real groups, through accessing mentoring and education training seminars for returned volunteers of sending organizations who had registered their consent in participating and were selected on the basis of the organizations' characteristics to obtain as diverse a range of organizations as possible. Focus groups were transcribed and analysed using content analysis (Kuckartz, 2014). Teasing out the volunteers' own description of their (learning) experiences enabled the triangulation of the quantitative results (Flick, 2011). Furthermore, to explore the effects of volunteers on their immediate social circles, survey respondents were asked at the end of the online questionnaire to share a link to a different questionnaire with: (1) their parent; and (2) their best friend. The data from this family and friends survey (a total of 914 persons had completed at least 50 per cent of the questionnaire) was analysed statistically to evaluate potential multiplier effects of the volunteers. The described quantitative and qualitative data are used together to answer the second research question.

\section{Conceptual framework: Principles and contents of weltwärts and education provisions in the SDGs}

This section starts by laying out the principles and contents (educational approach, intended education and behaviour outcomes) of the weltwärts programme as derived from its programme theory. We then juxtapose these principles and contents with the principles and contents of the education provisions in the 2030 Agenda, and discuss how far weltwärts aligns with them.

\section{Principles and contents of weltwärts}

On the level of principles, weltwärts aims to actively promote 'the principle of gender equality' (BMZ, 2016: 3; own translation). It positions itself also as an inclusive IVS that is open to all between the ages of, generally, 18 and 28 who show the 'interest and personal maturity required for participating in a development volunteer service' (BMZ, 2016: 5; own translation). A concept paper on strategies to achieve the diversification of weltwärts volunteers (Engagement Global, 2015) as well as so-called competence centres for promoting the access and participation of, specifically, people with disabilities, with vocational training or from immigrant backgrounds (Engagement 
Global, 2018) are in place to push for greater diversity among (potential) participating volunteers, for example through tackling information and access barriers, as well as structural issues such as programme length and programme cycles that hitherto have hindered the participation of diverse under-represented groups.

Other overall aims include building awareness of development issues in German society, and contributing 'to development-related information and education work in the spirit of "global learning"' (BMZ, 2016: 4). In this vein, weltwärts returnees can act as multipliers for development education work.

Global learning as a pedagogical concept is emphasized in central weltwärts programme documents and guidelines (BMZ, 2016; Engagement Global, 2014). Global learning aims to be 'preparation for living in world society' (Asbrand, 2008: 6; own translation), to educate so-called global citizens (Scheunpflug, 2000; Scheunpflug and Schröck, 2001). It is characterized by a multi-perspective approach, orientation towards the future, and a focus on transformation (of attitudes and behaviours; Keller et al., 2014). The goal is to equip individuals and groups with the capacity to build a liveable, peaceful and sustainable future (Bourn et al., 2016). While global learning, in principle, can take place in all geographical spaces, contact programmes such as international volunteer services can be seen as 'one important element of global learning' (FrietersReermann, 2010: 228; own translation).

In line with global learning, on the conceptual level of intended individual learning outcomes, we discerned five broad categories: knowledge, competences, attitudes, personality and behaviour. Envisaged knowledge outcomes include knowledge about the host country, and about global dependencies and their local consequences. In terms of competences, the aim is for volunteers to gain social and intercultural competences (for example, perspective-taking ability, intercultural communication skills), and to be able to maintain their capacity to act in the face of (actual or perceived) inconsistencies. Learning a language or acquiring methodological competences are other examples of envisaged competence gains. As for attitudes, changes include aspects such as a growing appreciation of the diverse forms of life and development, openness to intercultural encounters and the appreciation of the worth of global sustainability. Other aspects include learning to appreciate multiculturalism and developing a global identity. Envisaged personality changes comprise greater openness, the propensity to make contacts and the development of a positive self-image, as well as greater self-confidence, and higher self-efficacy and self-appreciation.

Consequently, these changes in knowledge, competences, attitudes and personality are meant to enable volunteers' active participation in the design and development of a sustainable society (which includes reflecting on the sustainability of one's own consumption patterns) and to motivate their undertaking of (developmentrelated) civic engagement in Germany upon their return (behaviour dimension).

\section{Principles and outcomes of weltwärts and in the 2030 Agenda}

To examine how far the principles and contents of weltwärts align with the education provisions in the SDGs, Table 1 presents an overview of principles and contents with regard to education in the 2030 Agenda (particularly SDG 4) and weltwärts. 
Table 1: Comparison of principles and contents in the 2030 Agenda/SDG 4 and weltwärts

\begin{tabular}{|c|c|c|}
\hline & 2030 Agenda/SDG 4 & weltwärts \\
\hline \multirow{4}{*}{$\begin{array}{l}\frac{0}{0} \\
\frac{0}{U} \\
\stackrel{\frac{E}{L}}{2} \\
0\end{array}$} & 'Leave no one behind' & Inclusive IVS \\
\hline & $\begin{array}{l}\text { SDG 4.5: eliminate gender disparities, } \\
\text { provide equal access for the vulnerable }\end{array}$ & $\begin{array}{l}\text { Promote gender equality; } \\
\text { open to all between the ages of } 18 \text { and } \\
28 \text { who display 'interest and personal } \\
\text { maturity' (BMZ, 2016: 5) }\end{array}$ \\
\hline & $\begin{array}{l}\text { 'Parity indices': disaggregate outcomes } \\
\text { by: } \\
\text { - sex or gender } \\
\text { - location (urban/rural) } \\
\text { - class or wealth } \\
\text { - disabilities } \\
\text { - affected by conflict } \\
\text { - indigenous status } \\
\text { - refugee or migrant status } \\
\text { - race or ethnicity } \\
\end{array}$ & $\begin{array}{l}\text { Promote access and participation of, } \\
\text { specifically: } \\
\text { - people with disabilities } \\
\text { - people with vocational training } \\
\text { - people with so-called migrant } \\
\text { backgrounds }\end{array}$ \\
\hline & 'Transforming our world' & $\begin{array}{l}\text { Contribute to building awareness of } \\
\text { development issues in German society; } \\
\text { achieve individual learning in volunteers }\end{array}$ \\
\hline \multirow{2}{*}{ 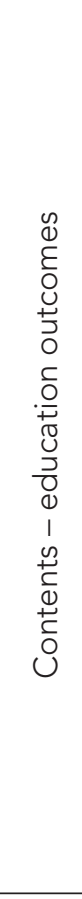 } & $\begin{array}{l}\text { SDG 4.7: provide knowledge and } \\
\text { skills for the promotion of sustainable } \\
\text { development }\end{array}$ & $\begin{array}{l}\text { Provide individual learning on dimensions } \\
\text { of: } \\
\text { - knowledge: about host country, } \\
\text { global dependencies and local } \\
\text { consequences } \\
\text { - competences: social and } \\
\text { intercultural competences, } \\
\text { capacity for action, methodological } \\
\text { competences, language skills }\end{array}$ \\
\hline & & $\begin{array}{l}\text { Provide individual learning on additional } \\
\text { dimensions of: } \\
\text { - attitudes: appreciation of } \\
\text { diversity and multiculturalism, } \\
\text { openness to intercultural } \\
\text { encounters, appreciation of global } \\
\text { sustainability, development of a } \\
\text { global identity } \\
\text { - personality: openness, propensity } \\
\text { to make contacts, positive self- } \\
\text { image, self-confidence, self- } \\
\text { efficacy, self-appreciation } \\
\end{array}$ \\
\hline 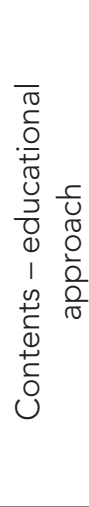 & $\begin{array}{l}\text { Education for: } \\
\text { - sustainable development } \\
\text { - } \text { sustainable lifestyles } \\
\text { - } \text { gender rights } \\
\text { - } \text { promotion of a culture of peace } \\
\text { - and nonviolence } \\
\text { - global citizenship } \\
\text { 'appreciation of cultural diversity } \\
\text { sustainable development' } \\
\text { (UN, 2015: n.p.) }\end{array}$ & $\begin{array}{l}\text { Global learning as pedagogical approach; } \\
\text { learning outcomes on the dimensions of } \\
\text { knowledge, competences, attitudes, and } \\
\text { personality (see cells above) }\end{array}$ \\
\hline
\end{tabular}




\begin{tabular}{|c|c|c|}
\hline & 2030 Agenda/SDG 4 & weltwärts \\
\hline \multirow{3}{*}{ 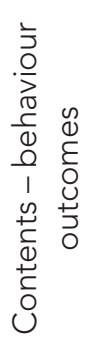 } & Promote sustainable development & $\begin{array}{l}\text { Participate actively in design and } \\
\text { development of a sustainable society }\end{array}$ \\
\hline & $\begin{array}{l}\text { Promote sustainable consumption and } \\
\text { production patterns }\end{array}$ & $\begin{array}{l}\text { Motivate to reflect on sustainability of } \\
\text { own consumption patterns }\end{array}$ \\
\hline & Young adults as change agents & $\begin{array}{l}\text { Returned volunteers as multipliers } \\
\text { (especially for development education } \\
\text { work); motivation for (development- } \\
\text { related) civic engagement }\end{array}$ \\
\hline
\end{tabular}

In terms of principles, we find that both the $2030 \mathrm{Agenda}$ and the weltwärts programme subscribe to inclusivity and gender equality along the lines of 'leave no one behind'. Weltwärts aligns with the call in the Agenda to achieve equitable access for diverse groups, although it focuses specifically on reaching people with disabilities, vocational training and immigrant backgrounds over other characteristics potentially related to inequality. Both the Agenda and weltwärts share a focus on transformation, even if at different levels: while the Agenda aims at 'transforming our world', at the microlevel weltwärts aims at transforming the participating volunteers and potentially other people through awareness-building in German society.

At the contents level, in terms of envisaged education outcomes, SDG 4.7 of the 2030 Agenda rather vaguely stipulates that 'knowledge and skills needed to promote sustainable development' (UN, 2015: n.p.) - what it exactly meant by these remains unclear. The programme theory constructed for weltwärts makes it possible to break down these dimensions (knowledge, competences) in much more concrete terms, and adds the dimensions of attitudes and personality change.

Some of the additional intended outcomes on the dimension of attitudes relate to the education areas mentioned in the educational approaches suggested in SDG 4.7. Here, particularly the attitude aspects of appreciation of diversity and multiculturalism, and of development of a global identity in weltwärts relate to the appreciation of cultural diversity and education for global citizenship in the SDGs. Overall, however, weltwärts more specifically emphasizes the approach of global learning. We do not view this as contradictory to the approaches outlined in SDG 4.7, as global learning also often addresses aspects of development, environment, peace, and human rights (Scheunpflug, 2000), and supports a vision for sustainable development (Große-Oetringhaus, n.d.). While global learning and its concurrent concepts, such as development education, global citizenship education and education for sustainability, each have their own genesis and focus, they also overlap and lines of definition are blurry (Bourn, 2015).

In terms of behaviour outcomes, the envisaged outcomes in weltwärts are also in line with the aims in the 2030 Agenda. Weltwärts returnees are to participate actively in the design and development of a sustainable society, echoing the promotion of sustainable development in the Agenda, and are to reflect on the sustainability of their own consumption patterns, echoing the promotion of sustainable consumption and production patterns in the Agenda. In terms of being change agents, it is hoped that returned volunteers will be multipliers, which puts a focus on the passing on of individual learning through the returnees. Here, weltwärts is much more concrete than the 2030 Agenda and names the areas of development education work and (development-related) civic engagement. 
In answer to the first research question on conceptual alignment, we then find that the principles and contents of weltwärts largely align with the provisions in the 2030 Agenda, and particularly SDG 4 with its sub-goals SDG 4.5 and SDG 4.7. Given the different levels and scope of the Agenda and weltwärts, it is not surprising that weltwärts is in some aspects both more detailed (for example, in the spelling out of particular knowledge and skills that are only mentioned in the abstract in SDG 4.7) and less encompassing (for example, specifically focusing on the inclusion of people with disabilities, with vocational qualifications and from immigrant backgrounds, instead of other vulnerable groups for equitable access, as stipulated in SDG 4.5, and pursuing one particular educational approach instead of several listed in SDG 4.7). While some attitudinal aspects (appreciation of multiculturalism and diversity, development of a global identity) reflect some of the educational areas put forward in SDG 4.7, personality aspects are not mentioned as envisaged education outcomes in the 2030 Agenda. As this theoretical outcome dimension adds to, rather than contradicts the education provisions in SDG 4.7, we conclude that, in terms of its conceptual framework, there is overall alignment of weltwärts with the SDGs.

\section{Practice: Are education outcomes in weltwärts in line with the SDGs?}

Working from the point of having established overall conceptual alignment, this section focuses on examining how far the outcomes actually achieved in weltwärts are in line with the SDGs on the implementation level in only those areas that also explicitly feature in the 2030 Agenda/SDG 4. These are: the principle of equitable participation (aligning with the 'leave no one behind' principle and SDG 4.5); the education outcomes of knowledge and competences, and the attitudinal aspects of appreciation of multiculturalism and diversity, as well as global identity (aligning with SDG 4.7); and the behaviour outcomes of sustainable consumption and of volunteers as multipliers (in civic engagement and development education work, aligning with the focus on change agents in the 2030 Agenda).

\section{Equitable participation in weltwärts}

Current participating weltwärts volunteers remain a very selective group of people. Based on the departing volunteer cohort of 2016 and the comparison group representing the target group of weltwärts, we ran binary logistic regression analysis to predict participation in weltwärts depending on different, mainly socio-demographic, factors. Table 2 provides an overview of the regression results (effects reported as exp[B]/odds ratios; significance level of 95 per cent).

Overall, the person most likely to participate in weltwärts is of female gender $(\exp [\mathrm{B}]$ male $=.52)$, aged 18 years (exp[B] 19 years or older $=.07)$, is from western Germany $(\exp [B]$ eastern Germany $=.47)$, from an upper-class (exp[B] lower class $=.51)$ and Christian background (exp[B] = 1.64), holding the Abitur (German general qualification for university entrance; $\exp [\mathrm{B}]=8.96)$, and not having a disability (exp $[\mathrm{B}]=.39)$. Holding an Abitur most markedly increases the probability of participation in weltwärts, which is also higher for those reporting a Christian religious affiliation. Being 19 years of age or above is the most prominent factor reducing the probability of weltwärts participation, followed by being affiliated to a religion other than Christianity (for example, to Islam or Judaism), and having a disability. 
Table 2: Factors increasing or decreasing the probability of participation in weltwärts

\begin{tabular}{lc}
\hline Factors influencing the probability of weltwärts participation & Model (exp[B]) \\
\hline Age: 19 years or older (vs 18 years) & $0.07^{\star}$ \\
Abitur (vs no Abitur [German university entrance qualification]) & $8.96^{\star}$ \\
Vocational qualification (vs no vocational qualification) & $0.58^{\star}$ \\
Male (vs female) & $0.52^{\star}$ \\
Disability (vs no disability) & $0.39^{\star}$ \\
Migrant background (vs no migrant background) & 0.90 \\
Religious affiliation: Christian (vs no religious affiliation) & $1.64^{\star}$ \\
Religious affiliation: other (vs no religious affiliation) & $0.27^{\star}$ \\
Place of origin: grew up in eastern Germany & $0.47^{\star}$ \\
(vs grew up in western Germany) & \\
Self-reported social class: lower class (vs upper class) & $0.51^{\star}$ \\
Self-reported social class: middle class (vs upper class) & 0.79 \\
Self-reported social class: preferred not to say (vs upper class) & $1.69^{\star}$ \\
\hline
\end{tabular}

Note: Survey of volunteers and target groups; 2016 cohort: $N=1,364$, target group: $N=4,316$.

${ }^{*} \mathrm{p}<.05, \exp [\mathrm{B}]$ reports standardized odds ratios; model fit: Nagelkerke's $\mathrm{R}^{2}=.687$,

Hosmer-Lemeshow test: $p=.828$, correctly predicted cases $=89.9$ per cent. Exp[B] express the probability of participation in weltwärts (dependent variable) occurring per one-unit rise in the given factors (independent variables), with values below 1 indicating a reducing probability, and values above 1 indicating a rising probability. This is an abridged version of the full regression table. Full regression results are reported in the Appendix (Table B).

Source: Table based on Polak et al. (2017b: 88, Table 77)

Along the lines of education, age, gender, disability, religion, location/geographical origin and class background, weltwärts does not yet achieve parity in the shares of persons coming from (multiple and intersecting) different groups. This is true also for people with disabilities, and those with vocational qualifications, two of the groups specifically targeted for increased participation in weltwärts. The measure of immigrant background did not have a significant effect in our analyses. We applied the Federal Statistical Office's definition, according to which persons are ascribed immigrant background (Migrationshintergrund) if they do not hold German citizenship; are naturalized; ethnic German (late) repatriates; or born as Germans in Germany to parents pertaining to any of the aforementioned groups (Statistisches Bundesamt, 2017; for a critical discussion of the term and conceptualization, see Perchinig and Troger, 2011). The results that reporting a non-Christian religious affiliation decreases participation probability might suggest some overlap with migration status, however, which would need careful disentangling of effects.

Weltwärts is not the only programme aiming at inclusivity but it is the only one achieving selectivity. Youth volunteer services in Germany generally attract only a small share of the population, and especially the well-educated, making youth volunteer services overall quite a specific form of civic engagement (Simonson et al., 2016). This trend seems to be especially pronounced in weltwärts. The over-representation of women is found in other IVS as well (AVID, 2018; Ecorys, 2013). Some, in particular the British International Citizen Service, also note different participation rates for different ethnic groups, with higher numbers of applicant volunteers identifying as White as opposed to Black, Asian, or Other (Ecorys, 2013; Morse, 2017). Differences 
in participation rates for different religious affiliations and belief systems (Frost and Edgell, 2018), as well as an over-representation of the socio-demographically or socioeconomically privileged is also apparent in different forms of volunteering more generally (for example, community volunteering or voluntourism; Benenson and Stagg, 2016; Lyons et al., 2012).

When viewed with regard to parity indices, we conclude that it is only in a very limited way that weltwärts currently achieves outcomes in line with the SDGs on the implementation of inclusivity. This points to a wider issue with the principles of inclusivity, equitable participation and gender equality subsumed under 'leave no one behind': might the idea of reaching 'all learners' (UN, 2015: n.p.; emphasis added) be too idealistic to ever be fully implemented by one instrument? And should precisely this idealism be an impetus to pursue the endeavour of equitable participation even more vigorously? Or should different instruments work together to reach all learners? Issues to overcome here could be, for example, tackling information barriers, systemic barriers to access and discriminatory practices (see Polak et al., 2017a). The disaggregation of data, as well as more qualitative data, could help in monitoring progress made on the issue (Howard and Burns, 2015).

\section{Education outcomes in weltwärts: Knowledge, competences, attitudes}

For those that do participate in weltwärts, the programme theory helped to operationalize the envisaged education outcomes. As neither the Agenda nor the Indicators suggest concrete items to represent the 'knowledge and skills' mentioned in SDG 4.7 (UN, 2015: n.p.), this operationalization is a vital step in testing the goal's implementation. We performed DiD-analyses (for items relating to general issues) and t-tests (for items relating to specific issues), as well as two-factor cross-tables analyses (for binary dependent variables) to determine the effects of weltwärts participation. Effects for DiD-analyses and t-tests will be reported in parentheses as effect sizes Cohen's d (small effect: Cohen's $d \geq .20$ and $<.50$; medium effect: Cohen's $d \geq .50$ and $<.80$; large effect: Cohen's $d \geq .80$; Cohen, 1977) and respective $p$-values to indicate whether or not effects are substantial. For cross-tables analyses, effects will be reported as the value for the test statistic Phi and respective p-values. Quantitative results will be complemented with evidence from the group discussions for those education outcomes mentioned in both weltwärts and SDG 4, that is for: the dimensions of knowledge (operationalized as knowledge about the host country and other countries more generally; see Appendix, Table A); competences (operationalized as language competences, methodological competences, specific and general perspective-taking ability, specific and general empathy, and intercultural self-efficacy); and attitudes (operationalized as multiculturalism and diversity beliefs). Are the outcomes that are aligned on the conceptual level achieved on the implementation level?

On the dimension of knowledge, returning weltwärts volunteers report significantly higher levels of knowledge about the host country than departing volunteers (moderate effect: Cohen's $d=0.76, p<.001$ ). Their knowledge about other countries more generally does not change (Cohen's $d=-0.19, p>.05$ ). These findings are supported by the group discussions.

Concerning competences, the following show significant increases: language skills (large effect: Cohen's $d=1.00, p<.001$ ); the returnees' ability to put themselves in the perspective of people from the host country (small effect: Cohen's $d=0.35, p<.001$ ); and the empathy towards the same people (small effect: Cohen's $d=0.26, p<.001$ ) - all 
making for social and intercultural competences. We found no significant effects for methodological competence (Cohen's $d=-0.07, p>.05$ ), more general empathy towards people from other countries (Cohen's $d=-0.13, p>.05$ ), or intercultural selfefficacy (Cohen's $d=-0.04, p>.05$ ). However, there is a significant negative effect for general perspective-taking ability (negative moderate effect: Cohen's $d=-0.53$, $p=<.001$ ). While not all types of competences analysed quantitatively get mentioned in the group discussions, the returnees emphasize the increase in language skills and a more general perspective-taking ability with regard to putting themselves in the shoes of someone who is (perceived to be) 'foreign' in another country.

When it comes to attitudes, there is no significant difference in the global identity reported (Cohen's $d=0.05, p>.05$ ), that is, returnees and departing volunteers report similar levels of agreement as to whether or not they identify as global citizens. Attitudes towards social diversity also remain unchanged: there is no significant difference in how returnees and departing volunteers rate the importance of a multicultural composition of German society (multiculturalism, Cohen's $d=-0.04, p>.05$ ) or the benefits of social and cultural diversity (diversity beliefs, Cohen's $d=-0.08, p>.05$ ). While the group discussions also do not make any explicit mention of multiculturalism, diversity beliefs or global identity, the ability to take the perspective of someone (perceived to be) 'foreign' and a greater openness to, and an appreciation of, intercultural encounters could be pointers towards a general openness to diversity.

In sum, weltwärts mostly manages to instigate individual learning that results in increased and more positive knowledge and competences in regard to the specific host country. Some intercultural skills also improve (language acquisition, specific perspective-taking ability and the ability to empathize with people from the host country). On the one hand, very concrete aspects of knowledge and skills are achieved by weltwärts in line with the SDGs on the implementation level. On the other hand, transfer of the acquired skills and knowledge to other contexts or wider issues is not made. Nor does identification as a global citizen or the appreciation of multiculturalism or diversity in society change, at least as measured by quantitative means. While the results from the group discussions point towards qualitative shifts in some of these aspects, for example by highlighting the ability to take on the perspective of those foreign or perceived to be foreign and hinting at a general openness to intercultural encounters, overall, more general aspects of knowledge, skills and attitudes in line with the SDGs are not fully achieved by weltwärts.

This is an important result, as it can stimulate the critical assessment of education endeavours such as IVS. In a review of English-language research evidence, Sherraden et al. (2008) note that some IVS formats might indeed not lead to a better general understanding of different cultures. In implementing education in line with the SDGs, unintended consequences, such as the reinforcement of stereotypes or global power structures (Haas, 2012; Kontzi, 2011), should therefore be given attention. Alternatively, it could be that volunteers put pre-departure high-level estimations of their competences into perspective and reach a more realistic view of themselves. Some volunteers might also develop a dislike for, or disapproval of, generalizations, and therefore rate items for constructs such as general perspectivetaking lower. Furthermore, it could be the case that participants with already positive attitudes in the areas of multiculturalism, diversity beliefs and global identity select into programmes such as weltwärts. This could in part reflect the overall selectivity of weltwärts participants - and thus provide more motivation to continue to reach out to a more diverse audience following the call to 'leave no one behind'. It could also suggest that envisaged education outcomes should be formulated in terms of 
consolidation, rather than further increases. Together, these observations call for a discussion of what precisely should and can be the 'knowledge and skills needed to promote sustainable development' (UN, 2015: n.p.). These impulses notwithstanding, on the implementation level, education outcome achievement in weltwärts is only partly in line with SDG 4.7, as the achieved education outcomes are mainly hostcountry related (specific knowledge, specific intercultural skills) but not transferred to a larger group of people, countries or cultures. Thus, a more global, relational perspective might not be reached.

\section{Behaviour outcomes in weltwärts: Sustainable consumption and returnees as multipliers}

In terms of individual sustainable behaviour, such as making an effort to engage in sustainable consumption, in the quantitative analysis, we find no significant effect of participation in weltwärts. At the same time, however, we find that the proportion of persons engaging in sustainable consumption is higher among the volunteers generally than among persons from the comparison group. The group discussions point to qualitative changes in sustainable consumption patterns. Returnees describe a conscious rejection of products, for example clothing, that were not sustainably produced. They also said that they made a point to promote activities that protect the environment, for example by paying attention to recycling and buying regional and seasonal produce.

Looking at the civic engagement and development education work aspects of returned weltwärts volunteers as multipliers, we find that volunteers generally (both pre- and post-departure) are active in civic engagement at above-average levels (76.7 per cent active in civic engagement in both returning and departing volunteers, Phi $=.000, d=.000, p>.05)$. This is a very clear result indeed. They are also active in civic engagement to a markedly and significantly higher level than persons in the comparison group (76.7 per cent of departing volunteers compared to 35.3 per cent of the departing volunteers' matched comparison group active in civic engagement, $P h i=.35, p<.001)$. While the proportion of the civically active does not change, the civic engagement exhibits a shift in focus towards a significantly higher share of returned volunteers engaging with development issues ( 46.4 per cent of returnees compared to 30.3 per cent of departing volunteers, Phi $=-.163, \mathrm{p}<.001)$. In the group discussions, returnees mentioned engagement in development issues in the broader sense of working with refugees, or in undertaking voluntary social support work, sometimes linked to the specific tasks they had undertaken at their place of assignment. We also find that the majority of returnees engage in development education work, for example, through organizing education and information events or through helping to facilitate seminars for new volunteers of their former sending organization (an aspect also mentioned in the group discussions).

We also uncover the 'multiplier' potential in weltwärts volunteers in inspiring individual change even in their immediate social circles. Comparing the scores of parents and friends of the respective returning and departing volunteers, we found pointers for the achievement of learning outcomes in the volunteers' family and friends. Both parents and friends of returning volunteers show increased knowledge about the volunteer's host country (parents: small effect, Cohen's $d=.44, p<.001$; friends: medium effect, Cohen's $d=.65, p<.001$ ); parents increase their positive attitudes (medium effect: Cohen's $d=0.50, p<.001$ ), and friends their empathy towards people from that host country (medium effect: Cohen's $d=0.54, p=.001$ ). These 
results show that, despite returnees in the group discussions reporting difficulties in communicating their experiences (for example, due to lack of interest from the people they talked to, or due to struggling to relate the whole picture of their stay abroad, or a fear of reinforcing stereotypes and clichés with their accounts), weltwärts volunteers nevertheless in part pass on their individual learning to others.

In terms of the promotion of sustainable development, with its aspects of sustainable consumption and returned volunteers acting as multipliers, weltwärts in principle achieves its envisioned outcomes, and is therefore, also on the implementation level, mostly in line with the provisions of the SDGs and the principles of the Agenda. Returnees report exploring more sustainable and environmentally conscious consumption patterns, they show a significant shift in their engagement towards development-related issues, and are active in development education work. In part, they also pass on some of their individual learning to persons in their immediate social circles, even though some communication difficulties are reported. Especially with regard to the strong effects found on the dimension of civic and development-related engagement, weltwärts seems to have the potential to 'channel their [the volunteers'] infinite capacities for activism into the creation of a better world' (UN, 2015: n.p.), or, to express it in humbler terms, at least into engagement for development-related issues.

\section{Conclusion}

In this article, we sought to bring together weltwärts, an exemplary IVS, and the 2030 Agenda to examine whether or not international volunteering in development can be viewed as an instrument for promoting education in line with the 2030 Agenda and its SDGs. We examined two questions: the first one relating to the alignment of principles and contents of weltwärts with education provisions in the SDGs on the conceptual level; the second focusing on the achievement of education outcomes through weltwärts in line with the SDGs on the implementation level.

On the conceptual level, we find overall alignment of weltwärts and the education provisions in the SDGs. Both support the principles of inclusivity and equitable participation (in line with the 'leave no one behind' principle) and share a focus on transformation. The contents of education outcomes and approaches of weltwärts also align with the provisions of SDG 4.7, although in places the former are more concrete (operationalizing knowledge and skills, for example), focused (emphasizing the education approach of global learning over other approaches), or provide additional aspects (adding the outcome dimensions of attitudes and personality changes). Working from this point of overall alignment in conceptual terms, we then examined the practical implementation of the principles and envisaged outcomes. Here we find a persistent selectivity of weltwärts participants. Young women from well-educated and often Christian backgrounds without disabilities have higher probabilities of participating in weltwärts than persons with vocational training qualifications or from other faiths. While the tendency to predominantly reach the socio-demographically or socio-economically privileged is also found in other IVS and volunteering more generally, this selectivity nevertheless points to shortcomings with regard to equitable participation on the implementation level. Education outcomes are also only partly achieved: we find learning effects in host-country-related and specific knowledge and skills, but not in the transfer of these to wider contexts. More positive attitudes towards multiculturalism, diversity and global identity cannot be found. While not all learning outcomes are attained, weltwärts returnees' activities in development-related civic engagement and development education work, and qualitative shifts in sustainable 
consumption are, also on the implementation level, overall in line with the promotion of sustainable development.

The methodological approach taken in this article combined document analysis to construct the programme theory, and discussion with key stakeholders to consolidate the programme theory, and a quasi-experimental design based on quantitative survey data complemented by qualitative focus group discussions to assess the effectiveness of the programme. First, this approach ensured that the empirical evaluation of weltwärts was clearly based on its theoretical framework. Second, it enabled rigorous quantitative theory testing through the DiD analysis to answer the second research question in particular. While we aimed at exploiting the strengths of both the quantitative and qualitative methods used as best as possible within the given questions, as well as within time and resource frames, a research approach guided by questions on more detailed information and explanation of the nuances of achieved outcomes might have used the qualitative data more fully. Even so, obtaining qualitative insights from the focus group discussions allowed us to uncover hints at potential theory reformulations and the need for more nuanced outcome operationalization.

Our results point to some potentials and limitations of weltwärts in promoting education in line with the SDGs. The main potential lies in the achievement of weltwärts in instigating behaviour changes in participating volunteers that make them active 'agents of change' in the promotion of sustainable development. While it has to be noted that weltwärts volunteers are, already pre-departure, a group active in civic engagement generally to above-average levels, the multiplier potential of weltwärts returnees is highlighted by the shift in their engagement focus to development issues, and their increased activity in development education work. Other empirical evidence cited suggests that this potential might also be found in other IVS (for example, Ecorys, 2013). When it comes to education outcomes, however, limitations remain with regard to achieving learning about wider contexts, and thus about structural issues, relationships and interdependencies. Yet this limitation on the implementation level exposes a potential on the conceptual level: as neither SDG 4.7 nor the Indicator Framework (UN, 2018) is particularly clear on what is to be understood exactly by the 'knowledge and skills needed to promote sustainable development' (UN, 2015: n.p.), weltwärts, with its detailed programme theory, offers a basis for engaging in a muchneeded conceptual discussion on how exactly these knowledge and skills should be formulated, operationalized, and potentially complemented by a focus on attitudes and personality aspects. This important exercise of detailing to a greater degree the contents in the 2030 Agenda, and SDG 4.7 in particular, of what needs to be learnt to promote sustainable development can, in turn, help weltwärts and other IVS to align their own conceptual frameworks and work more purposefully towards achieving education outcomes in line with the SDGs. Here, programme evaluations offer a useful tool in supporting this ongoing conceptual development and refinement, and indeed weltwärts can serve as an example of having drawn on such evaluations throughout its existence to continuously improve its conceptual framework and implementation achievements.

Last but not least, the persistent selectivity of weltwärts participants (and of those drawn towards IVS and volunteering in general) provides a reality check and food for thought with regard to the feasibility of truly achieving education for all. Is reaching 'all learners' (UN, 2015: n.p.; emphasis added), as stipulated in SDG 4.7 in the spirit of leaving 'no one behind', an ideal scenario (too) hard ever to be fully implemented by a single instrument? And should precisely this idealism be an impetus 
to pursue the endeavour of equitable participation even more vigorously, potentially through cooperation between different instruments? Despite the laudable measures of diversification concepts and competence centres for the inclusion of diverse target groups, the challenge for weltwärts remains to recruit volunteers from diverse levels of educational backgrounds, and different ages, genders, disabilities, religious affiliations, geographical origins and class backgrounds. The appeal in the Agenda to 'leave no one behind' could nevertheless be a powerful call for commitment that, if taken seriously, could provide the impetus for raising awareness about, and fuelling the motivation for, addressing truly all groups of society. It can give continued impetus to the efforts of weltwärts - and hopefully those of other IVS - in reaching as broad a societal spectrum of participants as possible.

In conclusion, weltwärts does not promote education in line with the SDGs unreservedly. It does, however, offer an inspiration to engage in the formulation of concrete operationalizations of knowledge and skills, and it does provide the change agents ready to promote sustainable development. At the same time, potential effects by which volunteers affect the host countries, places of assignment and their in situ accommodation were left unexplored in this article. We cannot, therefore, exclude the possibility of (unintended) negative consequences of weltwärts in the host countries that might hamper its alignment with, and contribution to promoting, the SDGs. This provides a topic for further research. In terms of individual learning, however, we contend that, by increasing its efforts to achieve the principles and contents that align with the SDGs on the conceptual level and by using the 'leave no one behind' aspiration of the Agenda as an impetus to fuel the work for truly equitable participation already being pursued, weltwärts, and other IVS, can prove an overall useful education instrument in promoting and achieving just, fair and sustainable futures (ideally) for all.

\section{Notes on the contributors}

Laura Scheinert is a trained sociologist and was an evaluator in the weltwärts evaluation team at the German Institute for Development Evaluation (DEval). She currently pursues a PhD in social sciences at the University of Exeter. She is also a trained multiplier for global learning.

Kerstin Guffler is trained in social psychology. She was an evaluator in the weltwärts evaluation and is currently Senior Evaluator and Team Leader of a study on 'German Development Cooperation from a Partner Perspective' at the German Institute for Development Evaluation (DEval). Before joining DEval, she completed a PhD in social psychology at the Philipps-Universität Marburg.

Jan Tobias Polak is trained in sociology. As former Team Leader, he was responsible for heading the weltwärts evaluation. He was Head of Evaluation and Statistics at the Austrian Development Agency (ADA) and is currently Senior Evaluator and Team Leader at the German Institute for Development Evaluation (DEval).

Martin Bruder, a social psychologist by training, is Head of one of DEval's evaluation departments and responsible for strategic evaluations in the areas of civil society development cooperation and human rights. He previously headed the Monitoring, Evaluation, Research section at the German Academic Exchange Service (DAAD). 


\section{References}

Angrist, J.D. and Pischke, J.-S. (2009) Mostly Harmless Econometrics: An empiricist's companion. Princeton: Princeton University Press.

Asbrand, B. (2008) 'Wie erwerben Jugendliche Wissen und Handlungsorientierung in der Weltgesellschaft?'. In VENRO e. V. (ed.) Jahrbuch Globales Lernen 2007/2008: Standortbestimmung - Praxisbeispiele - Perspektiven. Bonn: VENRO e. V., 1-8.

AVID (Australian Volunteers for International Development) (2018) Volunteers at a Glance 2016-17. Canberra: Department of Foreign Affairs and Trade.

Benenson, J. and Stagg, A. (2016) 'An asset-based approach to volunteering: Exploring benefits for low-income volunteers'. Nonprofit and Voluntary Sector Quarterly, 45 (1S), 131S-49S.

BMZ (Bundesministerium für wirtschaftliche Zusammenarbeit und Entwicklung) (2014) Konzept weltwärts - und danach? Die Rückkehrarbeit der weltwärts-Freiwilligen nach ihrem Freiwilligendienst. Bonn: Bundesministerium für wirtschaftliche Zusammenarbeit und Entwicklung.

BMZ (Bundesministerium für wirtschaftliche Zusammenarbeit und Entwicklung) (2016) Förderleitlinie zur Umsetzung des entwicklungspolitischen Freiwilligendienstes weltwärts. Bonn: Bundesministerium für wirtschaftliche Zusammenarbeit und Entwicklung.

Bourn, D. (2015) The Theory and Practice of Development Education: A pedagogy for global social justice. London: Routledge.

Bourn, D., Hunt, F., Blum, N. and Lawson, H. (2016) Primary Education for Global Learning and Sustainability (CPRT Research Survey 5). York: Cambridge Primary Review Trust.

Cerulli, G. (2015) Econometric Evaluation of Socio-Economic Programs: Theory and applications. Heidelberg: Springer.

Clark, J. and Lewis, S. (2017) Impact beyond Volunteering: A realist evaluation of the complex and long-term pathways of volunteer impact. London: Voluntary Service Overseas.

Cohen, J. (1977) Statistical Power Analysis for the Behavioral Sciences. Rev. ed. New York: Academic Press.

Devereux, P., Paull, M., Hawkes, M. and Georgeou, N. (2017) 'Volunteering and the UN sustainable development goals: Finding common ground between national and international volunteering agendas?'. Third Sector Review, 23 (1), 209-34.

Ecorys (2013) Evaluation of the International Citizen Service: Phase 1 report. London: Department for International Development.

Engagement Global (2012) Konzept für die Förderung von Begleitmaßnahmen im Rahmen des weltwärts-Programms. Bonn: Engagement Global gGmbh - Service für Entwicklungsinitiativen.

Engagement Global (2014) Qualitätsanforderungskatalog im weltwärts-Programm (Januar 2014). Bonn: Engagement Global gGmbh - Service für Entwicklungsinitiativen.

Engagement Global (2015) 'Abgleich des Konzepts zur Diversifizierung von Zielgruppen im weltwärts-Programm (2012) mit dem operativen Sachstand im Juli 2015'. Internal document.

Engagement Global (2018) 'Kompetenzzentren: Spezialisten für Zielgruppenerreichung'. Online. www.weltwaerts.de/de/kompetenzzentren.html (accessed 30 July 2018).

EuropeAid Co-operation Office Joint Evaluation Unit (2006) Evaluation Methods for the European Union's External Assistance: Volume 1: Methodological bases for evaluation. Luxembourg: Office for Official Publications of the European Communities. Online. https://tinyurl.com/y36b7oeg (accessed 9 March 2019).

Fitzmaurice, P. (2013) 'The impact of an international volunteering experience on individual career development'. In Benade, L. (ed.) Educational Provocations 2013 (Yearbook of the School of Education of the Auckland University of Technology). Auckland: Auckland University of Technology, 97-111.

Flick, U. (2011) Triangulation: Eine Einführung. 3rd ed. Wiesbaden: VS Verlag für Sozialwissenschaften.

Frieters-Reermann, N. (2010) 'Zwischen Normativität und Komplexität: Spannungsfelder und Widersprüche der entwicklungspolitischen Bildungsarbeit in Nichtregierungsorganisationen'. Gruppendynamik und Organisationsberatung, 41 (3), 219-33.

Frost, J. and Edgell, P. (2018) 'Rescuing nones from the reference category: Civic engagement among the nonreligious in America'. Nonprofit and Voluntary Sector Quarterly, 47 (2), 417-38.

Funnell, S.C. and Rogers, P.J. (2011) Purposeful Program Theory: Effective use of theories of change and logic models. San Francisco: Jossey-Bass.

Grobbauer, H., Höck, S., and Krier, J.-M. (2008) Evaluation der personellen Zusammenarbeit: Beitrag der Rückkehrerlnnen von HORIZONT3000 und Jugend Eine Welt zur entwicklungspolitischen Bildungs- und Öffentlichkeitsarbeit. Wien: ADA. 
Große-Oetringhaus, H.-M. (n.d.) Globales Lernen: Eine Einführung in das Thema. Online. https://tinyurl.com/y5yh7yzx (accessed 9 March 2019).

Guffler, K., Polak, J.T., Scheinert, L. and Bruder, M. (2018) 'Balancing methodological rigor and realworld constraints in evaluation: A mixed methods approach with quasi-experimental design component to impact assessment in cohort settings'. Manuscript submitted for publication.

Haas, B. (2012) Ambivalenz der Gegenseitigkeit: Reziprozitätsformen des weltwärtsFreiwilligendienstes im Spiegel der postkolonialen Theorie. Köln: Kölner Wissenschaftsverlag.

Haddock, M. and Devereux, P. (2015) Documenting the Contribution of Volunteering to the SDGs: The challenges and opportunities of universal SDGs for IVCOs and volunteer groups (Discussion Paper). International Forum for Volunteering in Development. Online. http://forum-ids.org/ wp-content/uploads/2015/12/Forum-Discussion-Paper-Documenting-the-Contribution-ofVolunteering-to-the-SDGs-final.pdf (accessed 13 April 2019).

Howard, J. and Burns, D. (2015) 'Volunteering for development within the new ecosystem of international development'. IDS Bulletin, 46 (5), 5-16.

Keller, J., Radeke, G., Büker, G., Schell-Straub, S., Hoffmann, K., Damasceno, S., Lopes, S., Vacha, A., Castanheira, A., Santos, A.T., Santos Silva, M., Cugler, N. and Cugler, M. (2014) Global What? A study on facts and needs of global learning in Germany, Portugal and Romania. Reutlingen: EPiZ.

Kontzi, K. (2011) 'Ich helfe, du hilfst, ... ihnen wird geholfen: Der Freiwilligendienst weltwärts reproduziert altbekannte Strukturen'. iz3w, 323, 40-42.

Kuckartz, U. (2014) Qualitative Inhaltsanalyse: Methoden, Praxis, Computerunterstützung. 2nd ed. Weinheim: Beltz Juventa.

Lemmer, G. and Wagner, U. (2015) 'Can we really reduce ethnic prejudice outside the lab? A metaanalysis of direct and indirect contact interventions'. European Journal of Social Psychology, 45 (2), 152-68.

Lough, B.J., Sherraden, M.S., Moore McBride, A. and Xiang, X. (2014) 'The impact of international service on the development of volunteers' intercultural relations'. Social Science Research, $46,48-58$

Lyons, K., Hanley, J., Wearing, S. and Neil, J. (2012) 'Gap year volunteer tourism: Myths of global citizenship?'. Annals of Tourism Research, 39 (1), 361-78.

Moore McBride, A., Lough, B.J. and Sherraden, M.S. (2012) 'International service and the perceived impacts on volunteers'. Nonprofit and Voluntary Sector Quarterly, 41 (6), 969-90.

Morse, A. (2017) International Citizen Service. London: National Audit Office.

Perchinig, B. and Troger, T. (2011) 'Migrationshintergrund als Differenzkategorie: Vom notwendigen Konflikt zwischen Theorie und Empirie in der Migrationsforschung'. In Polak, R. (ed.) Zukunft. Werte. Europa: Die Europäische Wertestudie 1990-2010: Österreich im Vergleich. Wien: Böhlau, 283-319.

Pettigrew, T.F. and Tropp, L.R. (2006) 'A meta-analytic test of intergroup contact theory'. Journal of Personality and Social Psychology, 90 (5), 751-83.

Polak, J.T., Guffler, K. and Scheinert, L. (2017a) Weltwärts Volunteers and Their Civic Engagement in Germany. Bonn: German Institute for Development Evaluation.

Polak, J.T., Guffler, K., and Scheinert, L. (2017b) Weltwärts-Freiwillige und ihr Engagement in Deutschland: Onlineanhang zum Evaluierungsbericht. Online. https://tinyurl.com/y59klgkm (accessed 10 March 2019).

Rosenbaum, P.R. and Rubin, D.B. (1983) 'The central role of the propensity score in observational studies for causal effects'. Biometrika, 70 (1), 41-55.

Scheunpflug, A. (2000) Die globale Perspektive einer Bildung für nachhaltige Entwicklung. Online. https://tinyurl.com/y2hegw5r (accessed 10 March 2019).

Scheunpflug, A. and Schröck, N. (2001) Globales Lernen. Stuttgart: Aktion Brot für die Welt.

Sherraden, M.S., Lough, B. and Moore McBride, A. (2008) 'Effects of international volunteering and service: Individual and institutional predictors'. Voluntas, 19 (4), 395-421.

Simonson, J., Vogel, C. and Tesch-Römer, C. (eds) (2016) Tabellenanhang: Freiwilliges Engagement in Deutschland: Der Deutsche Freiwilligensurvey 2014. Berlin: Deutsche Zentrum für Altersfragen.

Statistisches Bundesamt (2017) Bevölkerung und Erwerbstätigkeit: Bevölkerung mit Migrationshintergrund - Ergebnisse des Mikrozensus 2015 (Fachserie 1 Reihe 2.2). Wiesbaden: Statistisches Bundesamt.

Stern, T. et al. (2011) Der entwicklungspolitische Freiwilligendienst 'weltwärts': Bd. I: Hauptbericht. BMZ-Evaluierungsberichte. Bonn: Bundesministerium für wirtschaftliche Zusammenarbeit und Entwicklung. 
UN (United Nations) (2015) Transforming Our World: The 2030 Agenda for Sustainable Development (A/RES/70/1). New York: UN General Assembly. Online. https://sustainabledevelopment.un.org/content/documents/21252030\%20Agenda\%20for\%20 Sustainable\%20Development\%20web.pdf (accessed 13 April 2019).

UN (United Nations) (2018) Global Indicator Framework for the Sustainable Development Goals and Targets of the 2030 Agenda for Sustainable Development (A/RES/71/313 and E/CN.3/2019/2). Online. https://unstats.un.org/sdgs/indicators/Global\%20Indicator\%20Framework\%20after\%20 refinement_Eng.pdf (accessed 13 April 2019).

UNV (United Nations Volunteers) (n.d.) Volunteering for the Sustainable Development Goals. Bonn: United Nations Volunteers. Online. https://tinyurl.com/yynagr7t (accessed 10 March 2019).

Walther, F. (2013) Freiwilligendienste in Ländern des globalen Südens: Pädagogische Vorbereitung und Begleitung am Beispiel von "weltwärts". Köln: Kölner Wissenschaftsverlag.

Yashima, T. (2010) 'The effects of international volunteer work experiences on intercultural competence of Japanese youth'. International Journal of Intercultural Relations, 34 (3), $268-82$.

Zimmermann, J. and Neyer, F.J. (2013) 'Do we become a different person when hitting the road? Personality development of sojourners'. Journal of Personality and Social Psychology, 105 (3), 515-30.

\section{Appendix}

Table A: Operationalization of outcome dimensions: volunteer survey item texts and values for returning (2015 cohort, RV) and departing volunteers (2016 cohort, DV)

\begin{tabular}{|c|c|c|c|c|c|c|c|c|c|}
\hline \multirow{2}{*}{\multicolumn{2}{|c|}{$\begin{array}{l}\text { Outcome } \\
\text { dimension and } \\
\text { operationalization }\end{array}$}} & \multirow[b]{2}{*}{ Item text } & \multirow[b]{2}{*}{$\mathrm{RV} / \mathrm{DV}$} & \multicolumn{6}{|c|}{ Values ${ }^{a}$} \\
\hline & & & & 1 & 2 & 3 & 4 & 5 & $N$ \\
\hline \multirow{8}{*}{$\begin{array}{l}\frac{0}{0} \\
\frac{0}{0} \\
\frac{0}{3} \\
0 \\
\frac{1}{2}\end{array}$} & \multirow{4}{*}{ 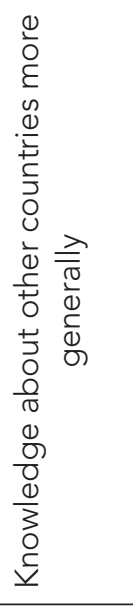 } & \multirow{2}{*}{$\begin{array}{l}\text { I know a lot about the } \\
\text { legal and economic } \\
\text { systems of other } \\
\text { countries. [Ich weiß viel } \\
\text { über die rechtlichen und } \\
\text { wirtschaftlichen Systeme } \\
\text { anderer Länder.] }\end{array}$} & RV & 54 & 197 & 150 & 74 & 14 & 489 \\
\hline & & & DV & 34 & 141 & 190 & 86 & 15 & 466 \\
\hline & & \multirow{2}{*}{$\begin{array}{l}\text { I know a lot about the } \\
\text { values and religions } \\
\text { prevalent in other } \\
\text { countries. [lch weiß viel } \\
\text { über die Werte und } \\
\text { die Religionen anderer } \\
\text { Länder.] }\end{array}$} & RV & 17 & 147 & 182 & 120 & 21 & 487 \\
\hline & & & DV & 12 & 97 & 200 & 138 & 19 & 466 \\
\hline & \multirow{4}{*}{ 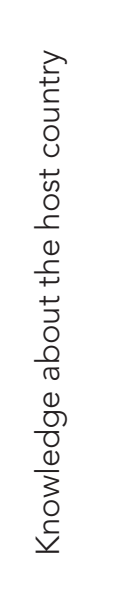 } & \multirow{2}{*}{$\begin{array}{l}\text { I know a lot about the } \\
\text { legal and economic } \\
\text { system of my host } \\
\text { country. [lch weiß viel } \\
\text { über das rechtliche und } \\
\text { wirtschaftliche System } \\
\text { meines Einsatzlandes.] }\end{array}$} & RV & 13 & 72 & 202 & 171 & 31 & 489 \\
\hline & & & DV & 25 & 120 & 216 & 97 & 8 & 466 \\
\hline & & \multirow{2}{*}{$\begin{array}{l}\text { I know a lot about the } \\
\text { values and religions } \\
\text { prevalent in my host } \\
\text { country. [lch weiß viel } \\
\text { über die Werte und } \\
\text { die Religionen meines } \\
\text { Einsatzlandes.] }\end{array}$} & RV & 0 & 5 & 76 & 264 & 144 & 489 \\
\hline & & & DV & 8 & 49 & 172 & 195 & 41 & 465 \\
\hline
\end{tabular}




\begin{tabular}{|c|c|c|c|c|c|c|c|c|c|}
\hline \multirow{2}{*}{\multicolumn{2}{|c|}{$\begin{array}{l}\text { Outcome } \\
\text { dimension and } \\
\text { operationalization }\end{array}$}} & \multirow[b]{2}{*}{ Item text } & \multirow[b]{2}{*}{ RV / DV } & \multicolumn{6}{|c|}{ Values $^{a}$} \\
\hline & & & & 1 & 2 & 3 & 4 & 5 & $\mathbf{N}$ \\
\hline \multirow{14}{*}{ 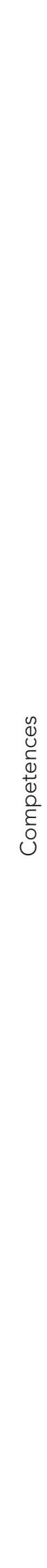 } & \multirow{2}{*}{ 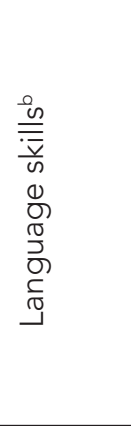 } & \multirow{2}{*}{$\begin{array}{l}\text { How would you rate your } \\
\text { current level of language } \\
\text { competence in the official } \\
\text { or common language of } \\
\text { your host country? [Wie } \\
\text { schätzt du deine aktuellen } \\
\text { Sprachkenntnisse } \\
\text { in der Landes- bzw. } \\
\text { Verkehrssprache deines } \\
\text { Einsatzlandes ein?] }\end{array}$} & $\mathrm{RV}$ & 1 & 33 & 100 & 237 & 118 & 489 \\
\hline & & & DV & 44 & 139 & 134 & 111 & 38 & 466 \\
\hline & \multirow{4}{*}{ 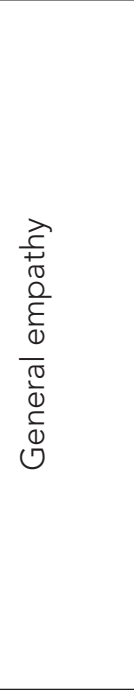 } & \multirow{2}{*}{$\begin{array}{l}\text { When I think of people } \\
\text { in developing countries I } \\
\text { feel sympathy for them. } \\
\text { [Wenn ich an Menschen } \\
\text { in Entwicklungsländern } \\
\text { denke, empfinde ich } \\
\text { Mitgefühl mit den } \\
\text { Menschen.] }\end{array}$} & $\mathrm{RV}$ & 16 & 76 & 164 & 161 & 71 & 488 \\
\hline & & & DV & 17 & 61 & 154 & 168 & 66 & 466 \\
\hline & & \multirow{2}{*}{$\begin{array}{l}\text { When I think of people } \\
\text { in developing countries } \\
\text { I feel solicitous for them. } \\
\text { [Wenn ich an Menschen } \\
\text { in Entwicklungsländern } \\
\text { denke, empfinde ich } \\
\text { Anteilnahme an ihrem } \\
\text { Leben.] }\end{array}$} & RV & 27 & 89 & 171 & 137 & 63 & 487 \\
\hline & & & DV & 16 & 64 & 155 & 160 & 71 & 466 \\
\hline & \multirow{4}{*}{ 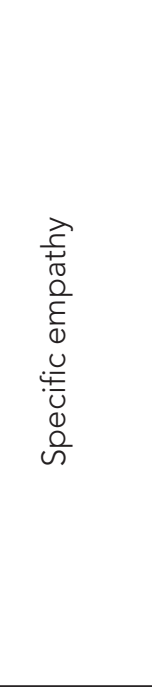 } & \multirow{2}{*}{$\begin{array}{l}\text { When I think of people } \\
\text { in my host country I } \\
\text { feel sympathy for them. } \\
\text { [Wenn ich an Menschen } \\
\text { aus meinem Einsatzland } \\
\text { denke, empfinde ich } \\
\text { Mitgefühl mit den } \\
\text { Menschen.] }\end{array}$} & RV & 30 & 87 & 137 & 153 & 81 & 488 \\
\hline & & & DV & 30 & 115 & 143 & 129 & 48 & 465 \\
\hline & & \multirow{2}{*}{$\begin{array}{l}\text { When I think of people } \\
\text { in my host country I } \\
\text { feel solicitous for them. } \\
\text { [Wenn ich an Menschen } \\
\text { aus meinem Einsatzland } \\
\text { denke, empfinde ich } \\
\text { Anteilnahme an ihrem } \\
\text { Leben.] }\end{array}$} & RV & 8 & 40 & 116 & 201 & 122 & 487 \\
\hline & & & DV & 9 & 61 & 128 & 195 & 72 & 465 \\
\hline & \multirow{4}{*}{ 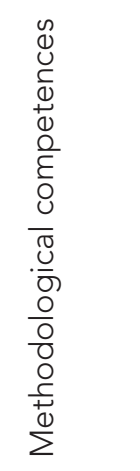 } & \multirow{2}{*}{$\begin{array}{l}\text { I am good at successfully } \\
\text { planning and } \\
\text { implementing projects. } \\
\text { [Ich bin gut darin, Projekte } \\
\text { erfolgreich zu planen und } \\
\text { durchzuführen.] }\end{array}$} & RV & 3 & 35 & 124 & 199 & 125 & 486 \\
\hline & & & DV & 0 & 23 & 121 & 223 & 96 & 463 \\
\hline & & \multirow{2}{*}{$\begin{array}{l}\text { I am capable of presenting } \\
\text { a topic in a structured way. } \\
\text { [Ich bin in der Lage, } \\
\text { ein Thema strukturiert } \\
\text { darzustellen.] }\end{array}$} & RV & 1 & 26 & 100 & 224 & 135 & 486 \\
\hline & & & DV & 0 & 19 & 81 & 228 & 135 & 463 \\
\hline
\end{tabular}




\begin{tabular}{|c|c|c|c|c|c|c|c|c|c|}
\hline \multirow{2}{*}{\multicolumn{2}{|c|}{$\begin{array}{l}\text { Outcome } \\
\text { dimension and } \\
\text { operationalization }\end{array}$}} & \multirow[b]{2}{*}{ Item text } & \multirow[b]{2}{*}{$\mathrm{RV} / \mathrm{DV}$} & \multicolumn{6}{|c|}{ Values $^{a}$} \\
\hline & & & & 1 & 2 & 3 & 4 & 5 & $\mathbf{N}$ \\
\hline & & $\begin{array}{l}\text { I am capable of solving } \\
\text { complex problems } \\
\text { independently. }\end{array}$ & RV & 0 & 20 & 100 & 255 & 111 & 486 \\
\hline & & $\begin{array}{l}\text { [lch bin in der Lage, } \\
\text { komplexe Aufgaben } \\
\text { selbstständig zu lösen.] }\end{array}$ & DV & 0 & 7 & 100 & 250 & 106 & 463 \\
\hline & & $\begin{array}{l}\text { I am confident of leaving } \\
\text { a good impression when } \\
\text { interacting with people } \\
\text { from other cultures. [Ich }\end{array}$ & RV & 3 & 19 & 97 & 249 & 120 & 488 \\
\hline & & $\begin{array}{l}\text { ich einen guten Eindruck } \\
\text { hinterlasse, wenn ich } \\
\text { mit Menschen anderer } \\
\text { Kulturen zu tun habe.] }\end{array}$ & DV & 1 & 12 & 81 & 270 & 102 & 466 \\
\hline & & $\begin{array}{l}\text { Even in unexpected } \\
\text { situations that can } \\
\text { arise from encounters } \\
\text { with people from other } \\
\text { cultures, I know that I } \\
\text { can trust my capabilities. } \\
\text { lAuch in unerwarteten }\end{array}$ & $\mathrm{RV}$ & 3 & 17 & 115 & 240 & 111 & 486 \\
\hline 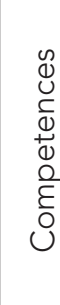 & 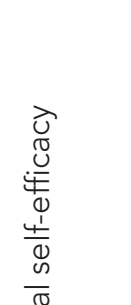 & $\begin{array}{l}\text { Situationen, die sich } \\
\text { aus der Begegnung } \\
\text { mit Menschen anderer } \\
\text { Kulturen ergeben können, } \\
\text { weiß ich, dass ich meinen } \\
\text { Fähigkeiten vertrauen } \\
\text { kann.] }\end{array}$ & DV & 1 & 16 & 118 & 233 & 97 & 465 \\
\hline & 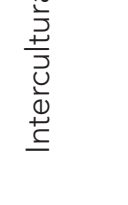 & $\begin{array}{l}\text { I am convinced that I } \\
\text { am capable of building } \\
\text { a good relationship } \\
\text { with people from } \\
\text { other cultures. [Ich bin }\end{array}$ & RV & 2 & 9 & 63 & 235 & 179 & 488 \\
\hline & & $\begin{array}{l}\text { überzeugt, dass ich in } \\
\text { der Lage bin, eine gute } \\
\text { Beziehung zu Menschen } \\
\text { anderer Kulturen } \\
\text { aufzubauen.] }\end{array}$ & DV & 0 & 8 & 43 & 257 & 158 & 466 \\
\hline & & $\begin{array}{l}\text { Even in situations of } \\
\text { special difficulty I can } \\
\text { trust my capabilities of } \\
\text { establishing positive } \\
\text { contact with people from } \\
\text { other cultures. [Auch unter }\end{array}$ & RV & 4 & 16 & 118 & 241 & 110 & 489 \\
\hline & & $\begin{array}{l}\text { erschwerten Bedingungen } \\
\text { kann ich meinen } \\
\text { Fähigkeiten vertrauen, } \\
\text { einen positiven Kontakt } \\
\text { mit Menschen anderer } \\
\text { Kulturen zu haben.] }\end{array}$ & DV & 0 & 13 & 96 & 254 & 103 & 466 \\
\hline
\end{tabular}




\begin{tabular}{|c|c|c|c|c|c|c|c|c|c|}
\hline \multirow{2}{*}{\multicolumn{2}{|c|}{$\begin{array}{l}\text { Outcome } \\
\text { dimension and } \\
\text { operationalization }\end{array}$}} & \multirow[b]{2}{*}{ Item text } & \multirow[b]{2}{*}{$\mathrm{RV} / \mathrm{DV}$} & \multicolumn{6}{|c|}{ Values $^{a}$} \\
\hline & & & & 1 & 2 & 3 & 4 & 5 & $\mathbf{N}$ \\
\hline \multirow{12}{*}{ 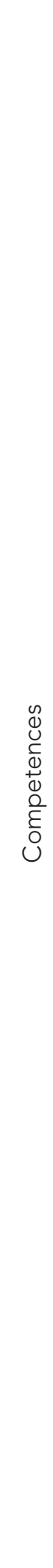 } & \multirow{6}{*}{ 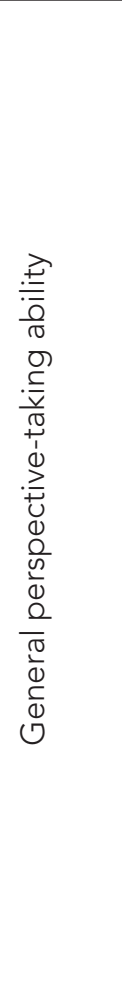 } & \multirow{2}{*}{$\begin{array}{l}\text { I believe I have a good } \\
\text { understanding of how } \\
\text { people from other } \\
\text { cultures see the world. } \\
\text { [Ich glaube, ich habe ein } \\
\text { gutes Verständnis dafür, } \\
\text { wie Menschen anderer } \\
\text { Kulturen die Welt sehen.] }\end{array}$} & RV & 25 & 112 & 167 & 151 & 34 & 489 \\
\hline & & & DV & 13 & 53 & 154 & 195 & 50 & 456 \\
\hline & & $\begin{array}{l}\text { I think of myself as } \\
\text { capable of seeing the } \\
\text { world through the eyes } \\
\text { of people from other }\end{array}$ & RV & 47 & 123 & 154 & 131 & 33 & 488 \\
\hline & & $\begin{array}{l}\text { ich bin in der Lage, die } \\
\text { Welt mit den Augen } \\
\text { von Menschen anderer } \\
\text { Kulturen zu sehen.] }\end{array}$ & DV & 18 & 37 & 135 & 212 & 63 & 465 \\
\hline & & $\begin{array}{l}\text { I can easily put myself in } \\
\text { the shoes of people from } \\
\text { other cultures. [lch kann }\end{array}$ & RV & 32 & 110 & 184 & 122 & 41 & 489 \\
\hline & & $\begin{array}{l}\text { mich leicht in Menschen } \\
\text { aus anderen Kulturen } \\
\text { hineinversetzen.] }\end{array}$ & DV & 13 & 43 & 177 & 183 & 49 & 465 \\
\hline & \multirow{6}{*}{ 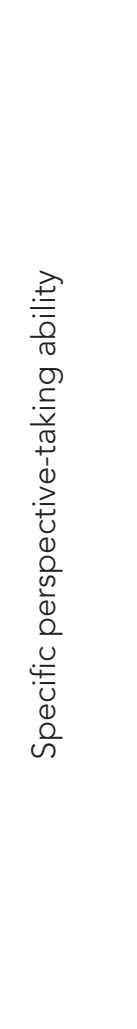 } & \multirow{2}{*}{$\begin{array}{l}\text { I believe I have a good } \\
\text { understanding of how } \\
\text { people from my host } \\
\text { country see the world. } \\
\text { [Ich glaube, ich habe ein } \\
\text { gutes Verständnis dafür, } \\
\text { wie Menschen aus meinem } \\
\text { Einsatzland die Welt } \\
\text { sehen.] }\end{array}$} & $\mathrm{RV}$ & 2 & 26 & 84 & 277 & 100 & 489 \\
\hline & & & DV & 16 & 85 & 176 & 159 & 28 & 464 \\
\hline & & \multirow{2}{*}{$\begin{array}{l}\text { I think of myself as } \\
\text { capable of seeing the } \\
\text { world through the eyes } \\
\text { of people from my host } \\
\text { country. [Ich denke, ich bin } \\
\text { in der Lage, die Welt mit } \\
\text { den Augen von Menschen } \\
\text { aus meinem Einsatzland zu } \\
\text { sehen.] }\end{array}$} & RV & 25 & 52 & 137 & 204 & 71 & 489 \\
\hline & & & DV & 21 & 40 & 133 & 214 & 57 & 465 \\
\hline & & \multirow{2}{*}{$\begin{array}{l}\text { I can easily put myself in } \\
\text { the shoes of people from } \\
\text { my host country. [Ich kann } \\
\text { mich leicht in Menschen } \\
\text { aus meinem Einsatzland } \\
\text { hineinversetzen.] }\end{array}$} & RV & 11 & 55 & 163 & 199 & 60 & 488 \\
\hline & & & DV & 20 & 52 & 189 & 157 & 45 & 463 \\
\hline
\end{tabular}




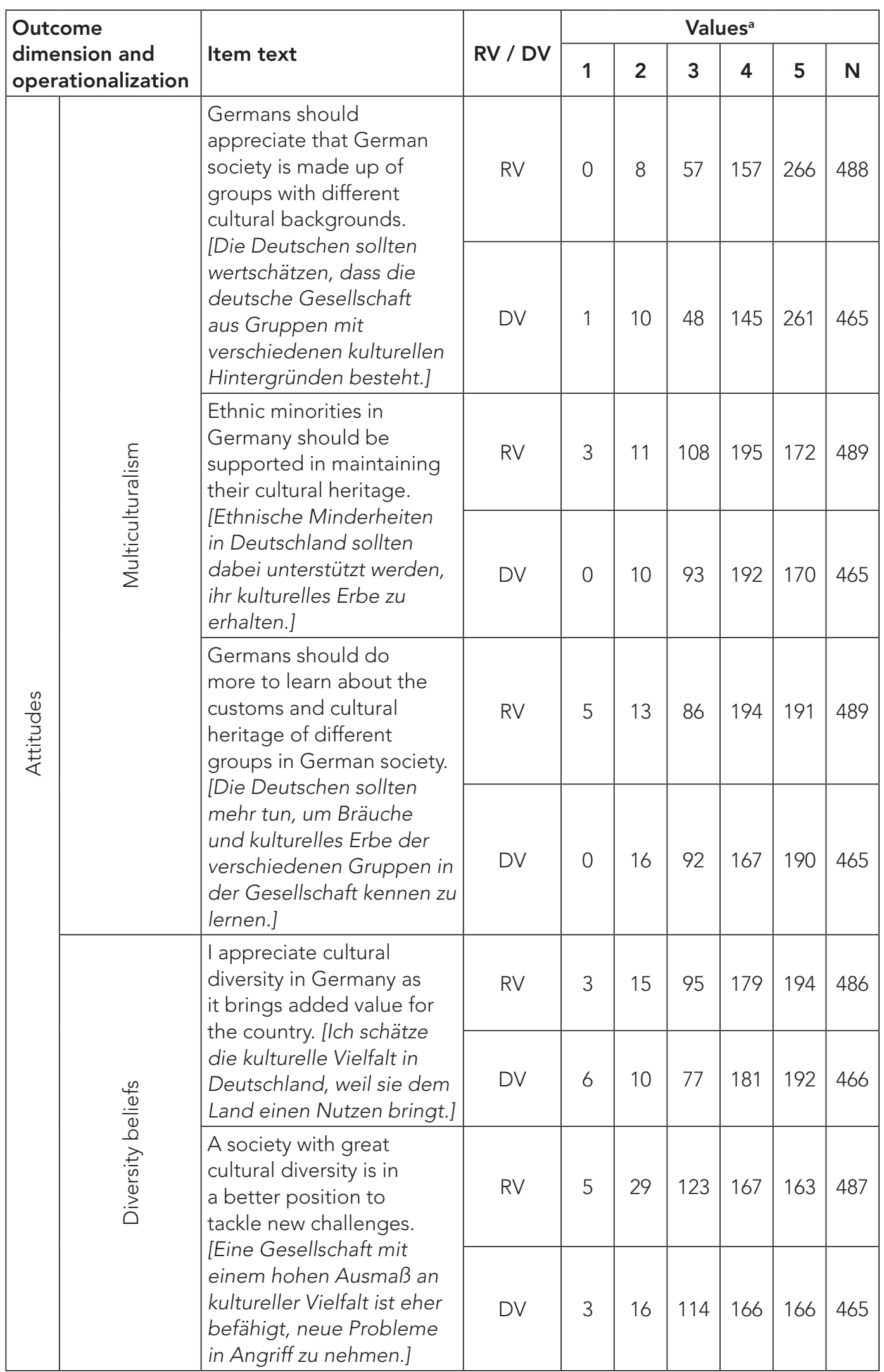

Note: Survey of volunteers, 2016 cohort (departing volunteers, DV) and 2015 cohort (returning volunteers, RV) matched.

a For the majority of items, values are labelled 1 ('Don't agree at all') to 5 ('Agree completely').

${ }^{b}$ In this case, values are labelled 1 ('No skills at all') to 5 ('Very good skills').

Source: Table based on Polak et al. (2017b: 58, Table 44) 
Table B: Factors increasing or decreasing the probability of participation in weltwärts (full regression table)

\begin{tabular}{lc}
\hline Factors influencing the probability of weltwärts participation & Model (exp[B]) \\
\hline Age: 19 years or older (vs 18 years) & $0.07^{\star}$ \\
Abitur (vs no Abitur [German university entrance qualification]) & $8.96^{\star}$ \\
Vocational qualification (vs no vocational qualification) & $0.58^{\star}$ \\
Male (vs female) & $0.52^{\star}$ \\
Disability (vs no disability) & $0.39^{\star}$ \\
Migrant background (vs no migrant background) & 0.90 \\
Religious affiliation: Christian (vs no religious affiliation) & $1.64^{\star}$ \\
Religious affiliation: other (vs no religious affiliation) & $0.27^{\star}$ \\
Place of origin: grew up in eastern Germany & $0.47^{\star}$ \\
(vs grew up in western Germany) & \\
Self-reported social class: lower class (vs upper class) & $0.51^{\star}$ \\
Self-reported social class: middle class (vs upper class) & 0.79 \\
Self-reported social class: preferred not to say (vs upper class) & $1.69^{\star}$ \\
Political affiliation (left-right) & $0.46^{\star}$ \\
Interest in development politics & $1.84^{\star}$ \\
Civic engagement & $2.92^{\star}$ \\
Volunteers' social circles: interest in development cooperation & 0.93 \\
Volunteers' social circles: own volunteer service experience & 0.96 \\
Openness & $1.14^{\star}$ \\
Risk-taking propensity & $1.48^{\star}$ \\
\hline
\end{tabular}

Note: Survey of volunteers and target groups; 2016 cohort: $N=1,364$, target group: $N=4,316$.

${ }^{*} \mathrm{p}<.05, \exp [\mathrm{B}]$ reports standardized odds ratios; model fit: Nagelkerke's $\mathrm{R}^{2}=.687$, Hosmer-Lemeshow test: $p=.828$, correctly predicted cases $=89.9$ per cent Source: Table based on Polak et al. (2017b: 88, Table 77) 